\title{
Enforcement of Consumer Protection Laws on Halal Products: Malaysian Experience
}

\author{
Mustafa 'Afifi Ab. Halim¹ \& Azlin Alisa Ahmad² \\ ${ }^{1}$ Faculty of Syariah and Law, Universiti Sains Islam Malaysia, Bandar Baru Nilai, Malaysia \\ ${ }^{2}$ Faculty of Islamic Studies, Universiti Kebangsaan Malaysia, Bandar Baru Bangi, Malaysia \\ Correspondence: Mustafa 'Afifi Ab. Halim, Faculty of Syariah and Law, Universiti Sains Islam Malaysia, 71800 \\ Bandar Baru Nilai, Nilai, Negeri Sembilan, Malaysia. E-mail: afifiusim@gmail.com; afifi@usim.edu.my
}

Received: August 28, 2013 Accepted: September 19, $2013 \quad$ Online Published: January 27, 2014

doi:10.5539/ass.v10n3p9 URL: http://dx.doi.org/10.5539/ass.v10n3p9

This title is a research being conducted by the authors with the use of research funds FRGS (USIM/FRGS-FSU-32-51512) to obtain an information and to develop a model of consumer protection halal products in Malaysia.

\begin{abstract}
Halal industry is a market that has not been fully explored and they have a very good potential in the future. This is supported by the larger number of world's Muslim community, estimated at a total of 1.8 billion in 2011, with the current value of the Halal market is estimated to reach USD2.3 trillion. However, there are some issues regarding the Halal industry both domestic and international, particularly in relation to the abuse of the Halal logo and other offenses relating to Halal logo. Apart from that, there are also other challenges, particularly in the enforcement of the relevant laws of Halal certification. The objective of this article is to look into the consumer protection and enforcement of Halal related laws that have been implemented by State Religious Department which are Religious Department of Selangor (JAIS) and Religious Department of Kelantan (JAHEIK). Other objectives of this paper is to improve and enhance the enforcement and monitoring of Halal certification for the benefit of consumers and producers and educate them to have a responsibility in producing a Halal product.
\end{abstract}

Keywords: consumer law, Halal, Halal standards, consumer protection, law enforcement

\section{Introduction}

The Halal industry is growing rapidly not only in Malaysia but throughout the country. The high demand for this industry has led the industry in striving to meet the consumer demands which consist of not only Muslim consumers, but it has started to become the choice of consumers of various places, races and religions. This situation is also led by the increase of Muslims around the world where the number of Muslims are 1.8 billion in 2011 and they are knowledgeable and have a high economic level (Mustafa \& Kamilah, 2012) which caused the demand for Halal products to surge. Most Muslim countries under the World Islamic Organization has also started producing their own Halal standards to ensure that the Halal standards in their respective countries are consistent with the Islamic standards (Mustafa \& Mahyeddin, 2012).

However, despite the favourable development of the Halal industry, the Muslim community in this country is still dealing with the issues of Halal certificate forgery, food processing issues that are not in accordance with Islamic law, the issue of uncertain food content and the cleanliness. This should be addressed immediately to avoid doubts about the status of Halal products as a new source of global economic growth. Thus, the effectiveness of Halal law needs to be improved.

In addition, the Halal status of products in the market should not be underestimated by the Muslim users in particular. Before the amendments of the Trade Descriptions Act 2011, there are many cases of fraud Halal logo that has been done by the dealer or manufacturer of Halal products that claim their products are Halal, but in reality it is not (Note 1).

Based on the cases that have been reported, it shows that most of the vendors or manufacturers of the products had been deceptive and made false representations to consumers, especially in the use of Halal label. The question to 
be raised is whether the rights of consumers being better protected after the amendment of the Trade Descriptions Act 2011 to consumers in Halal products? As far as this writing is made, there are no cases of prosecutions brought to court due to abuse of the Halal logo. Ministry of Domestic Trade, Cooperatives and Consumerism (MDTCC) have stated that a total of 29 cases was reported in 2012 and only 1 case was settled with a compound of Ringgit Malaysia 3 thousand while the rest was seized and their goods confiscated which values about fifteen thousand Ringgit Malaysia (Roslan, 2012). This article will study issues related to the enforcement of Halal in the Selangor Islamic Religious Department (JAIS) and the Kelantan Islamic Affairs Department (JAHEIK).

\section{Enforcement of Halal Certification Law in Malaysia}

Law and Halal guidelines have long been implemented, but there are still many lacuna in terms of the effectiveness of the law and its implementation in Malaysia. This is evident when consumers are confused and sceptical of the Halal status of a food or products marketed.

\subsection{Before the Amendments of the Trade Descriptions Act 2011 (TDA 2011)}

Before the amendments of TDA were made in 2011, the applied laws and acts related to the enforcement of Halal were not subject to the jurisdiction of the Malaysia Department of Islamic Development (JAKIM). Their jurisdiction is only on certification process. JAKIM use Malaysian Standards (MS) and the Manual of Malaysian Halal Certification Procedure for Halal certification (Kamilah \& Mustafa 2012).

In addition, the Trade Descriptions (Use of "Halal") Order 1975 gives way to individuals or private companies to issue its own certificate and Halal logo. This was because, the Order did not mention the names of JAKIM or the State Islamic Religious Department (JAIN) / State Islamic Religious Council (MAIN) exclusively as the competent agencies authorized to issue a Halal certificate and logo (Kamilah \& Mustafa 2012).

\subsection{After the Amendments of the Trade Descriptions Act 2011}

Amendments were made to the TDA 2011 that empowered JAKIM to carry out enforcement against traders who abuse the use of the Halal logo on their products. It is enshrined in Order 3 of the Trade Descriptions (Certification and Marking of Halal) Order 2011. However, the Ministry of Domestic Trade, Co-Operative and Consumerism (MDTCC) still pursuing the enforcement on issues related to Halal products during the transition period of TDA 2011 enforcement (Mustafa \& Kamilah, 2012).

According to Chief Assistant Director of Halal Hub Division JAKIM, Azizan bin Shaari, in the process of strengthening the Halal enforcement division in Malaysia, JAKIM is trying to increase the number of competent enforcers to carry out their duties in accordance with the amended Trade Descriptions Act 2011 (Mustafa \& Kamilah, 2012).

JAKIM now has the power to prosecute and thereby, JAKIM should have qualified officers to practise in the civil court because the jurisdiction of Halal products prosecution, either according to TDA 2011 or other legislation related to Halal products, comes under the jurisdiction of the civil court. Meanwhile, the state Chief Prosecutors have the power to prosecute for offences under the State Criminal Offences Enactment (Mustafa \& Kamilah 2012).

\section{Halal Enforcement Case Study in JAIS and JAHEAIK}

The lack of a complete law on the issue of Halal has made enforcement of existing laws cannot be implemented effectively. This is based on several factors:

\subsection{Halal Related Laws}

Prior to 2011, the applied law was the Trade Descriptions Act 1972, under the Ministry of Domestic Trade, Cooperatives and Consumerism. When the act was revised, the ministry came to conclusion that the act should be updated, and due to that, the amendments were made to the Trade Descriptions Act 2011. This Act gives power to the minister of the domestic trade, co-operatives and consumerism to appoint a competent authority to deal with Halal issues. Therefore, the MDTCC appointed JAKIM, JAIN and MAIN as the competent parties in this context (Roslan, 2012).

Therefore, by-laws have been created to support the Trade Descriptions Act 2011. Among them are the Trade Descriptions (Definition of Halal) Order 2011, the Trade Descriptions (Certification and Marking of Halal) Order 2011, and the Trade Descriptions (Halal Certification and Marking Fees) Order 2011. All of these three by-laws are enforced from the $1^{\text {st }}$ of January 2012 (Roslan, 2012).

Among the reasons for the laws related to Halal created under TDA 2011 and the by-laws referred to above is to ensure that the is only one authority responsible for issuing the Halal endorsement which is either the JAKIM or 
the JAIN/MAIN, giving enforcement powers to only one party which is the MDTCC, and ensure the 'self declaration' of Halal is not allowed (Roslan, 2012).

Meanwhile, the Food Act 1983 is the parent to the current food legalities, and under it comes the Food Regulations 1985, the Health Food Regulations 2009 and a number of new regulations that have been gazetted such as the Food Radiation Regulations (Badruzzaman, 2012).

JAKIM recognizes the Halal certification implemented by the State Islamic Religious Council (MAIN) / Department of Religious Affairs (JAIN).

In the context of JAIS, Section 38 of the Selangor Syariah Criminal Enactment No. 9 of 1995 states that "any person who exhibits, on any food or drink that is not lawful, any sign which indicates that the food or drink is Halal, is guilty of an offence and upon conviction, liable to a fine not exceeding two thousand Ringgit or to imprisonment for a term not exceeding one year or both" (Solihin, 2012).

\subsection{Jurisdiction}

Two parties recognized by the Malaysian government to issue Halal certification in Malaysia are JAIN or MAIN and JAKIM. It is enshrined in Article 74 (2) read together with the Ninth Schedule, State List of the Federal Constitution of Malaysia states that matters pertaining to Islamic law and Muslim individual and family law are under the jurisdiction of the state (Mustafa \& Kamilah, 2012). Halal is a matter pertaining to Islamic law and is under the jurisdiction of the state. However, the state's jurisdiction is limited only to Muslims.

Due to this circumstances, the enforcement of TDA 2011 is to ensure that the action can be taken by JAIN, MAIN and JAKIM towards non-Muslim who abuse Halal label.

\subsection{Staff Constraints}

In the context of JAIS, only fifteen staffs were assigned to the Halal Management Section, Division of Research and Development of JAIS which is headed by an Assistant Director of the Section (Solihin, 2013). Of the fifteen assigned, seven staffs are assigned under the Consultation and Accreditation Unit; four staffs working under the Supervision and Audit Unit, three given the responsibility under the Halal Development Unit whilst the last one staff is the administrative assistant (Solihin, 2013).

Meanwhile, there are only ten people who work under the Assistant Director (Halal Management) JAHEAIK (Zawawi, 2013). Of the ten assigned, two are working under the Faith and Syariah Unit, four working under the Halal Management Unit, and four working under the Administrative Unit (Zawawi, 2013).

Based on the number of staffs involved, JAIS and JAHEIK find it quite difficult to carry out the enforcement of Halal certification abuse because they have to deal with the application of Halal certification, Halal audit and provide education to the community.

\subsection{Enforcement Training and Preparation}

JAKIM and MAIN need to provide courses and training in relation to the investigation and prosecution. To facilitate enforcement, the MDTCC has appointed JAKIM officers and state Islamic officers as enforcement officers are called as assistant trade description controllers under the Trade Descriptions Act 2011. So far, the ministry has appointed a total of 240 people from JAKIM, JAIN and MAIN. Courses relevant to the investigation and prosecution should be held and should be further enhanced as to create dedicated law enforcement officers, the relevant knowledge should be deepened as exposure on how to make raids, prosecutions, inspections and knowledge of acts such as the Evidence Act, the Criminal Procedure Code and others (Roslan, 2012).

However, the constraints arise in the context of training the JAIS and JAHEAIK officers. Since there are no strict selection sessions to elect JAIS and JAHEAIK officers, there are officers who do not give their full commitment to the assigned task (Ahmad Solihin, 2013). There are some officers who are not willing to face the challenges of enforcement duties (Zawawi, 2013). Apart from the issues of affordability, efficiency and competency of the officers, JAIS and JAHEAIK also had to deal with the transfer of staffs or officers in the department due to promotions or normal exchange (Zawawi, 2013) Because of this, many officers are not capable of acquiring the required level of skills (Zawawi, 2013).

\subsection{Other Enforcement Challenges Faced by the JAIS and JAHEAIK}

Other challenges faced in enforcement are:

1) The use of Halal logo voluntarily

All these while, the consumers assume that the use of Halal logo is compulsory but actually the use Halal logo is not compulsory for traders. When the use of Halal logo was voluntary, these traders used the Halal logo as they 
wished. The actions of these traders have caused some confusion among consumers in terms of the Halal status of those products and premises (Zawawi, 2013).

2) Halal logo as an attraction to Muslim consumers and users in general

Halal logo is used indiscriminately by traders and manufacturers. They assume that if there is no sign of Halal, then the consumers will not buy the products or enter their premises. Some of them also felt Halal sign is very hard to be obtained to run their business. Therefore, they use the Halal mark without applying for it with the related authority (Roslan, 2012).

3) Halal debate and expression of the perceptions of Muslims

Public's perceptions about the products made by Muslims are Halal. Halal is not just to comply with Islamic law but it also covers aspects of food safety and hygiene of food premises (Roslan, 2012).

4) Solving cases take a long time

Settling a case is taking so long. This is because, in order to produce a good case, the investigating officers had to refer to various parties. In terms of certification, the MDTCC had to refer to the JAIS and JAHEIK to verify the authenticity of the Halal certificate. In terms of verification of a product, whether it's pork or not, it is slaughtered or not, the MDTCC refers to a third party, such as the Department of Chemistry, Ministry of Health, or the Department of Veterinary Services to see whether the contents of the items are as described. Therefore, the expected settlement of cases cannot be achieved (Roslan, 2012).

\section{Findings and Conclusions}

In achieving the aim of making Malaysia as the world's Halal hub, various issues and challenges arose in relation to the enforcement of Halal certification in Malaysia. Therefore, the government and the authorities should immediately take steps to address these issues because it has major implications on the Muslim community in particular. There are several proposed improvements to address these issues and challenges as follows:

1) JAKIM and MAIN need to provide courses and training in relation to the investigation and prosecution. To facilitate enforcement, the MDTCC has appointed JAKIM officers and state Islamic officers as enforcement officers are called as assistant trade description controllers under the Trade Descriptions Act 2011. So far, the ministry has appointed a total of 240 people from JAKIM, JAIN and MAIN. Courses relevant to the investigation and prosecution should be held and should be further enhanced as to create dedicated law enforcement officers, the relevant knowledge should be deepened as exposure on how to make raids, prosecutions, inspections and knowledge of acts such as the Evidence Act, the Criminal Procedure Code and others.

2) Expand public awareness campaigns in order for the public to file a complaint related to Halal abuse to the authorities.

3) Set up a special commission to govern Halal matters in Malaysia.

4) Create specific Halal law to govern Halal legislations. Without effective laws, various problems will arise that may thwart government's efforts to lift the Halal industry as a new source of world economic development.

5) Ongoing effort to bring awareness to consumers about the importance of choosing foods on display.

In compliance with the amendments to the Trade Descriptions Act 2011, where this act has named JAKIM or JAIN/MAIN as a competent authority, the authority in issuing the Halal certificate. This means that, based on the TDA 2011, any individual or private company cannot simply issue the Halal expression or logo unless issued by JAKIM or JAIN only. Prior to this amendment, the authority permits any individual or private companies to issue its own certificate and Halal logo. Thus, TDA 2011 gave a great impact and effect in terms of Halal law enforcement in Malaysia.

JAIM, JAIS and JAHEIK are examples of institutions that governs the Halal matters in the country, but they face many constraints in the management of Halal that needs to be realized by the government and at the same time need to be improved, particularly in terms of staffs so that the Halal industry can be protected from any fraud.

\section{References}

Halim, M. A. A., \& Mohd, K. W. (2012). Keberkesanan Penguatkuasaan Undang-undang berkaitan produk Halal bagi perlindungan pengguna. Paper work conference of Fiqh Muamalah and Current Fiqh Issues.

Halim, M. A. A., \& Salleh, M. M. M. (2012). The Possibility of Uniformity on Halal Standards in Organization of Islamic Countries (OIC) Country. World Applied Sciences Journal, 17.

Interview with Ahmad Solihin Bin Maryakon, Assisstant Director (Halal Management Section), Research and 
Development Department JAIS, held in Bangunan Sultan Idris Shah, Shah Alam, Selangor, on 16 Januari 2013.

Interview with Nik Mohamad Zawawi Bin Ibrahim, Assisstant Director (Halal Management Unit), Research and Management Division JAHEAIK, held in Bangunan JAHEAIK, Kompleks Islam Darulnaim, Kota Bharu, Kelantan, on 6 Januari 2013.

Mahayudin, M. R. (2012). Undang-undang Pensijilan Halal: Cabaran Penguatkuasaan serta Cadangan Penambahbaikan. Forum 1: Seminar Penguatkuasaan Undang-undang berkaitan Halal: Implikasi kepada Industri Halal di Malaysia held on 10 Disember 2012 at IKIM, Kuala Lumpur.

Mohd, K. W., \& Halim, M. A. A. (2012). $1^{\text {st }}$ Volume. Keberkesanan Undang-undang Halal yang berkesan. $2^{\text {nd }}$ Proceeding of International Syariah and Common Law 2012.

Rahim, B. A. (2012). Undang-undang Pensijilan Halal: Cabaran Penguatkuasaan serta Cadangan Penambahbaikan. Forum 1: Seminar Penguatkuasaan Undang-undang berkaitan Halal: Implikasi kepada Industri Halal di Malaysia held on 10 Disember 2012 at IKIM, Kuala Lumpur.

\section{Note}

Note 1. Example of cases reported by the press as the dealer has acquired a Halal logo but then misused the logo, Halal certification has expired or the company never obtained a Halal certificate but used a fake certificate. There are cases also reported by the mainstream media where there is a business that uses Halal logo for their products, but the results of the investigation showed that the products contained alcohol or deoxyribonucleic acid (DNA) of pork which is forbidden in Islam. Among the cases reported by the Department of Islamic Development Malaysia (JAKIM) are the results of the analysis conducted by the Chemistry Department of Malaysia in samples of HP Sauce and Tabasco Pepper Sauce which confirmed the presence of pork's deoxyribonucleic acid (DNA) in their products (Revoke Sale of Products found with pig DNA. The Star. 17th June; Sijil Halal Kerajaan Perlu Tegas. Utusan Malaysia. June 17). Meanwhile, Utusan Malaysia reported that Muslims are reminded not to use Golden Churn Pure Creamery Butter after Jakim confirmed that their products were not Halal (Golden Churn Pure Creamery Butter tidak Halal. Utusan Malaysia. 7th April). Utusan Malaysia reported on the three directors of Rail Passion Sdn. Limited. (Rail Passion) was charged in the Magistrate's Court on two charges of selling coffee containing the pork deoxyribonucleic acid (DNA) in their shop, Kluang Rail Coffee without putting its existence statement on the label of the coffee packaging (Three Directors, Manufacturers of pork DNA Coffee charged. Utusan Malaysia. 20th May). Meanwhile, Muslim consumers are advised to carefully select bread, pastries and cakes based food in the market after JAKIM cancelled the Halal certification application of a supplier company located in Europe which supplies non-Halal ingredients to several well-known supermarkets and restaurants in the country (DNA Babi: JAKIM Batal Sijil Halal Syarikat Bekal Ramuan Roti. Utusan Malaysia. 18th May).

\section{Appendix}

\section{Statutes}

Abattoirs (Privatization) Act 1993

Animals Act 1953 (Revised 2006)

Animal Rules 1962

Animal (Importation) Order 1962

Customs Act 1967

Customs (Prohibited Imports) Regulations 1998

Federal Constitution

Food Act 1983

Food Regulations 1985

Local Government Act 1976

Syariah Criminal Offences (Federal Territories) Act 1997

Syariah Criminal Enactment (Selangor) 1995 
Trade Descriptions Act (TDA) 2011

Trade Marks Act 1976

Trade Descriptions (Definition of Halal) Order 2011

Trade Descriptions (Certification and Marking of Halal) Order 2011

Trade Descriptions (Certification and Marking of Halal Fees) Order 2011

Trade Marks Regulations 1997

\section{Copyrights}

Copyright for this article is retained by the author(s), with first publication rights granted to the journal.

This is an open-access article distributed under the terms and conditions of the Creative Commons Attribution license (http://creativecommons.org/licenses/by/3.0/). 